高血圧性脳内出血急性期に招ける CT scan の造影剂増強効果

北原 正和 小川 彰 小松 伸郎
桜井 芳明 鈴木 二郎*

要旨：発症 8 時間以内の高血圧性脳内出血症例に括いて contrast-enhanced CT scan 上大脳 半球に洆漫性の enhancement 効果を認めた 21 例について検討した。このうち両側大脳半球に enhancement 効果を認めたもの $(\mathrm{CE}(+))$ は 7 例，血腫側大脳半球のみのもの $(\mathrm{CE}(+))$ は 4 例, enhancement 効果を認めなかったもの $(\mathrm{CE}(-))$ は10例であった。 以上の 3 群について 入院時意識レベル，血腫量等との関係について検討した。入院時意識レベルは, CE (一) では $3-3-9$ 度で $0-3: 9$ 例, 10-30：1 例, $\mathrm{CE}(+)$ は $0-3: 2$ 例, 10-30:2 例, $\mathrm{CE}(+)$ は10-30：1例, 100-300：6 例, 血腫量は, $\mathrm{CE}(-)$ では $38 \pm 22 \mathrm{~cm}^{3}, \mathrm{CE}(+)$ は $50 \pm 12 \mathrm{~cm}^{3}$, $\mathrm{CE}(+\mathrm{H})$ は $114 \pm 27 \mathrm{~cm}^{3}$ であり, 発症急性期の高血圧性脳内出血に括ける enhancement 効果の 出現は, 血腫量及び臨床症状の重症度と有意に相関した。また，この enhancement 効果の出現 機序は, 脳血管反応性の障害あるいは頭蓋内圧え進による脳血管床の増大が考えられた。

Key words : intracerebral hematoma, acute stage, computerized tomography, enhancement effect

(脳卒中 $5: 180-185,1983$ )

\section{I.はじめに}

我々は大脳基底核部高血圧性脳内出血の急性期に抒 いて, CT scan 上 contrast enhancementにより，血 腫側から時に反対側に及ぶ大脳皮質領域に造影剤増強 効果が出現する症例のあることに注目し, 報告してき た518). 今回はこの現象が臨床的にいかなる意義を有す るかを検討するため, 発症 8 時間以内に contrast enhancement CT scanを施行した大脳基底核部高血圧 性脳内出血症例について, 急性期の造影剂増強効果の 有無と臨床像との比較検討を行ない，さらにこの造影 剤増強効果の出現機序について考察を加えた.

\section{II. 対象及び方法}

対象症例は過去 2 年間に, 国立仙台病院脳卒中セン ターに来院した大脳基底核部高血圧性脳内出血症例 中, 発症 8 時間以内に CT scan を施行した21例であ る。この内訳は，男性14例，女性 7 例，年齢分布は 20 歳台 1 例， 30 歳台 4 例，40歳台 2 例，50歳台 10 例， 60

国立仙台病院脳卒中センター, 脳神経外科

* 東北大学脳研脑神経外科
歳台 3 例, 70 歳台 1 例である. CT scan 装置は島津 SCT-100N を使用し, $\mathrm{OMO}^{\circ}$ で $2 \mathrm{~cm}$ から $9 \mathrm{~cm}$ まで, $1 \mathrm{~cm}$ 毎に plain CTを施行し，この後アンギオグラ フィン $100 \mathrm{ml}$ を約 5 分間で静注し, 静注直後に同様の 条件下で CT scan を施行した。 造影剂増強効果の有無 は写真上で plain CT scan と比較することにより判定 し, 両側大脳皮質に造影剂増強効果を認めるものを $\mathrm{CE}(H)$ (Fig. 1), 認められないものを $\mathrm{CE}(-$ ) (Fig. 2 ) とし, 患側大脳半球のみに認められたものを $\mathrm{CE}$ （十）とした。 以上の 3 群について, 入院時意識状態, 発症から CT scan 施行までの時間, 血腫部位, 血腫量 の比較検討を行なった. 尚, 血腫量は CT scan 写真上 から各スライスにおける high density areaの面積を 算出し,さらに拡大率を乗じ, それにスライス幅 $1 \mathrm{~cm}$ を乗じ, 各スライスの值を加算することにより求めた。

\section{III. 結 果 (Table 1)}

\section{1）造影剤増強効果の有無とその出現部位}

contrast enhancement CT scanを施行した21例中 造影剂増強効果を認めた症例は11例であった（症例 11 21). 造影剂増強効果は大脳皮質に広範囲に㼛漫性 出現し，5ち両側大脳皮質に及ぶ造影剂増強効果を認 
Table 1 Enhancement effect of hypertensive intracerebral hematoma in an acute stage.

Enhancement Effect (-) : no enhancement effect. $(+)$ : enhancement effect in the affected side of cerebral hemisphere. $(H)$ : enhancement effect in the bilateral cerebral hemisphere.

* Extravasation of the contrast media.

\begin{tabular}{|c|c|c|c|c|c|c|c|}
\hline Case & Age & Sex & $\begin{array}{l}\text { Enhancement } \\
\text { Effect }\end{array}$ & $\begin{array}{l}\text { Consciousness } \\
\text { Level }\end{array}$ & $\begin{array}{c}\mathrm{CT} \text { timimg } \\
\text { (hrs) }\end{array}$ & $\begin{array}{l}\text { Type of } \\
\text { Hematoma }\end{array}$ & $\begin{array}{l}\text { Volume of } \\
\text { Hematoma (cc) }\end{array}$ \\
\hline 1 & 68 & $\mathrm{M}$ & - & 1 & 2 & lateral & 30 \\
\hline 2 & 54 & $\mathrm{M}$ & - & 2 & 6.5 & medial & 60 \\
\hline 3 & 57 & $\mathrm{M}$ & - & 2 & 3 & medial & 20 \\
\hline 4 & 65 & $\mathrm{M}$ & - & 3 & 5 & medial & 20 \\
\hline 5 & 37 & $\mathrm{M}$ & - & 3 & 1.5 & lateral & 50 \\
\hline 6 & 55 & $\mathrm{~F}$ & $\cdots$ & 3 & 6.5 & medial & 10 \\
\hline 7 & 46 & $\mathrm{M}$ & - & 3 & 4 & combined & 60 \\
\hline 8 & 52 & M & - & 3 & 4 & combined & 30 \\
\hline 9 & 51 & $\mathrm{~F}$ & - & 3 & 5 & lateral & 20 \\
\hline 10 & 53 & $\mathrm{~F}$ & - & 30 & 7 & medial & 80 \\
\hline 11 & 46 & $\mathrm{M}$ & + & 3 & 7 & lateral & 30 \\
\hline 12 & 53 & $\mathrm{~F}$ & + & 3 & 2 & medial & 50 \\
\hline 13 & 55 & M & + & 10 & 2.5 & lateral & 60 \\
\hline 14 & 24 & M & + & 30 & 1 & lateral & 60 \\
\hline 15 & 54 & F & $H^{*}$ & 20 & 3 & combined & 80 \\
\hline 16 & 34 & F & $H$ & 100 & 5 & medial & 90 \\
\hline 17 & 33 & M & H & 200 & 5 & medial & 150 \\
\hline 18 & 52 & $\mathrm{M}$ & $H$ & 200 & 6 & combined & 130 \\
\hline 19 & 60 & M & $H$ & 200 & 7.5 & combined & 100 \\
\hline 20 & 37 & $\mathrm{~F}$ & + & 200 & 2 & combined & 100 \\
\hline 21 & 72 & $\mathrm{M}$ & $H^{*}$ & 300 & 6 & combined & 150 \\
\hline
\end{tabular}

めたもの $(\mathrm{CE}(+))$ は 7 例であり（症例15-21），患側 大脳皮質にのみ造影剂増強効果を認めたもの（CE (十)) は 4 例であった（症例11〜14）。また血腫壁に接 する脳組織に斑点状の造影剂増強効果が認められ, 造 影剂の血管外漏出と考兄られたものが 2 例あった（症 例15，21). 他の10例では造影剤増強効果は認められな かった。

\section{2）入院時意識レベルと造影剂増強効果の関係} (Table 2)

造影剂増強効果の認められなかった10例の入院時意 識レベルは $3-3-9$ 度方式で， 9 例が 1 〜 3 のレベ ルであり，1例のみが30であったが，患側大脳皮質に のみ造影剂増強効果を認めた $(\mathrm{CE}(+)) 4$ 例では, 意 識レベル 3 が 2 例，10〜30が 2 例であった。ささらに反 対側大脳皮質にまで造影剤増強効果を認めた（CE (H)） 7 例は， 1 例が意識レベル20であった他は 100〜300のレベルで，高度の意識障害を呈しており， 造影剂増強効果の有無と程度は有意に意識障害の重症
Table 2 Relationship between enhancement effect and level of consciousness.

$\mathrm{CE}(-)$ : no enhancement effect. $\mathrm{CE}(+)$ : enhancement effect in the affected side of cerebral hemisphere. $\mathrm{CE}(H)$ : enhancement effect in the bilateral cerebral hemisphere

\begin{tabular}{c|c|c|c|c}
\hline $\begin{array}{c}\text { Consciousness } \\
\begin{array}{c}\text { Enhance- Level } \\
\text { ment Effect }\end{array}\end{array}$ & $0 \sim 3$ & $10 \sim 30$ & $100 \sim 300$ & $P$ \\
\hline CE (-) & 9 & 1 & 0 & $\mathbb{P}_{0.05}^{0.05}$ \\
$\mathrm{CE}(+)$ & 2 & 2 & 0 & $\bigotimes_{0.01}^{0.01}$ \\
$\mathrm{CE}(H)$ & 0 & 1 & 6 & \\
\hline
\end{tabular}

度と相関していた。

3） CT 施行時期と造影剤増強効果の関係 (Table 1) 造影剂増強効果の認められなかった症例は発症から $\mathrm{CT}$ 施行までの時間は 1.5 乃至 7 時間で, 平均 $4.5 \pm 1.8$ 時間であった。 また患側大脳皮質にのみ造影剂増強効 果の認められた症例 $(\mathrm{CE}(+))$ は 1 乃至 7 時間, 平均 $3.1 \pm 2.3$ 時間であり，両側大脳皮質に造影影剂増強効 
果を認めた症例 $(\mathrm{CE}(+))$ は 2 乃至7.5時間, 平均 $4.9 \pm$ 1.7時間で,これらの間に憶な差は認められなかっ た。

4）血腫型と造影剂增強効果の関係（Table 1) 造影剤増強効果の認められなかった10例の血腫部位

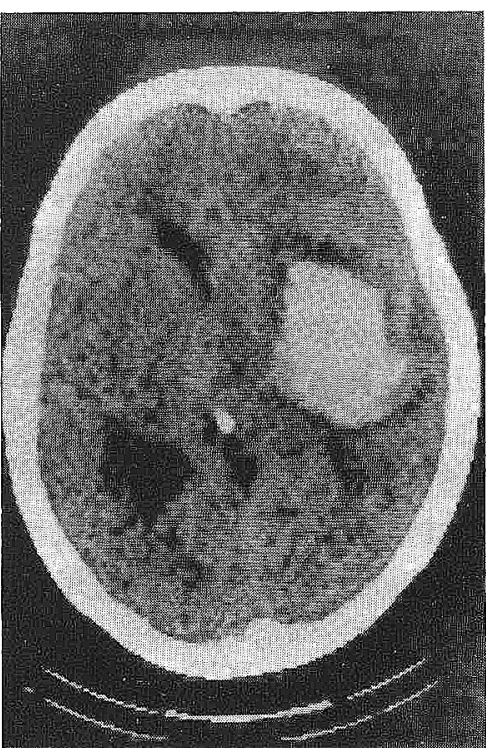

a : plain CT
は，外側型 3 例，混合型 2 例，内側型 1 例であった。 一方，両側大脳皮質に認められた $(\mathrm{CE}(+)) 7$ 例は， 混合型 5 例，内側型 2 例で岁り，一側大脳皮質に造影 剤増強効果の認められた $(\mathrm{CE}(+)) 4$ 例では，外側型 3 例，内側型 1 例であった。

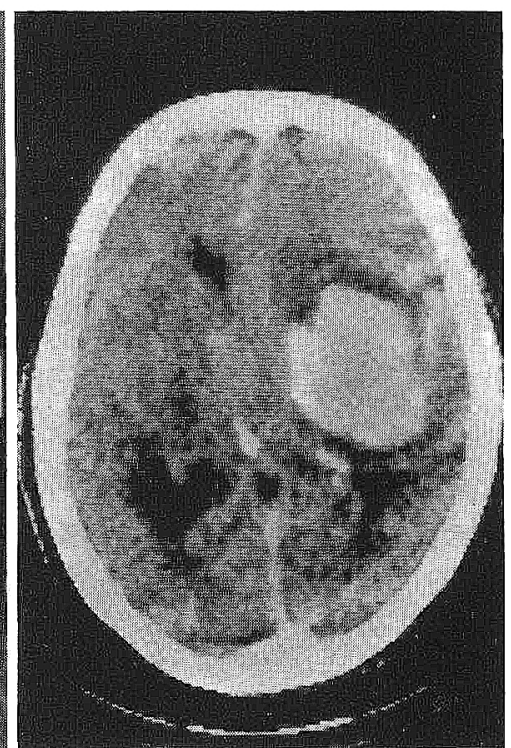

b : contrast enhancement. CT.

Fig. 1 Case 15, 54-year-old female : the contrast enhancement effect is observed in the bilateral cerebral cortex and the inner surface of the hematoma.

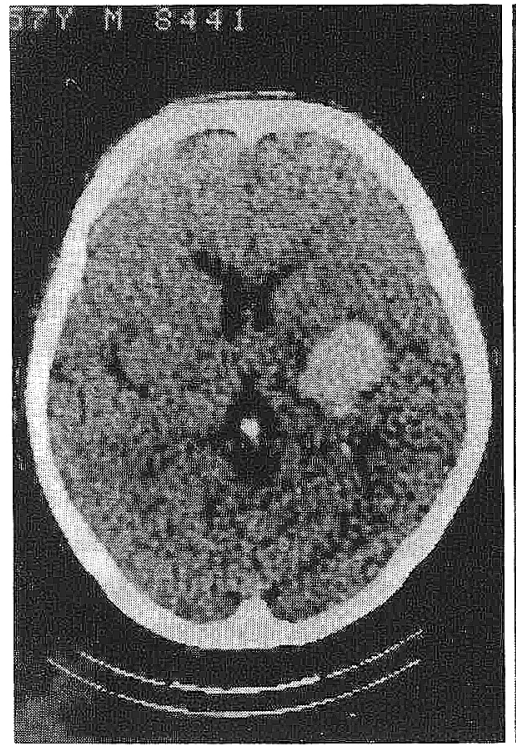

a : plain CT

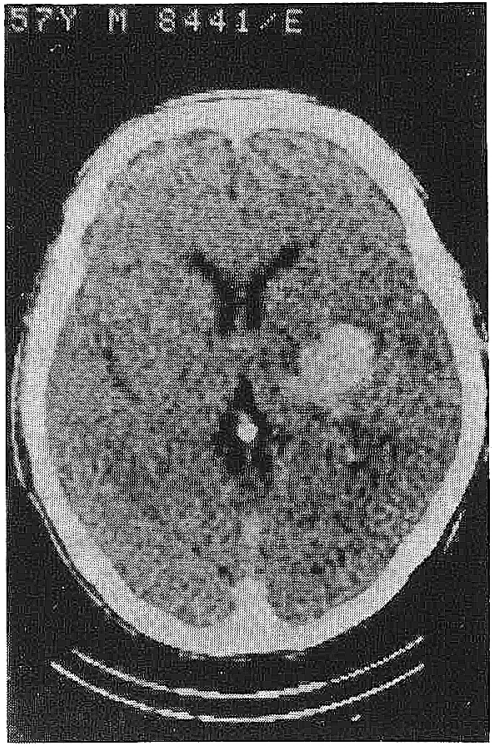

$\mathrm{b}:$ contrast enhancement $\mathrm{CT}$

Fig. 2 Case 3, 57-year-old male : Contrast enhancement effect was not evident. 


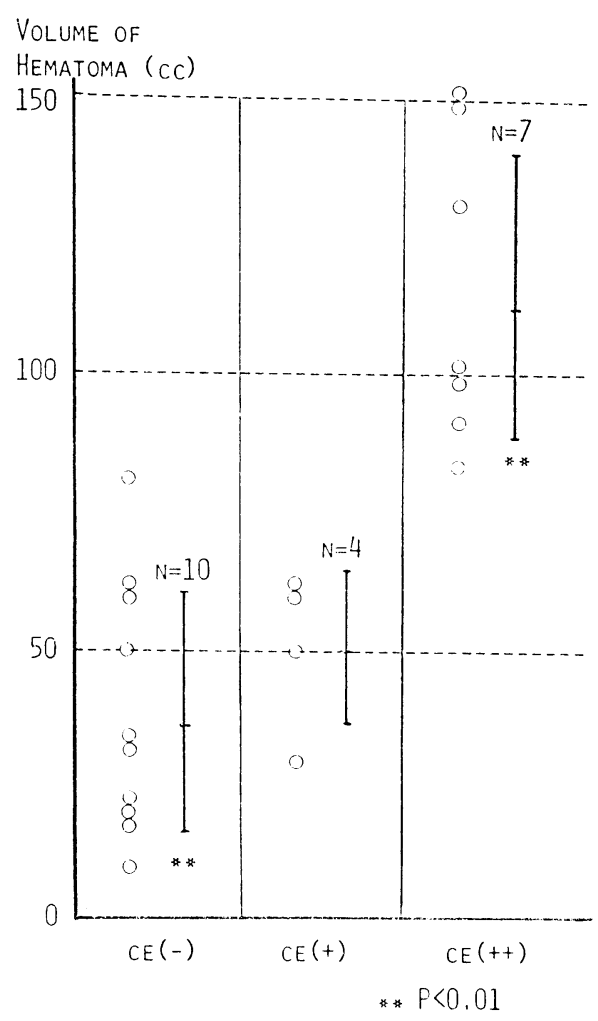

Fig. 3 Relationship between enhancement effect and volume of hematoma.

$\mathrm{CE}(-)$ : no enhancement effect. $\mathrm{CE}(+)$ : enhancement effect in the affected side of cerebral hemisphere. $\mathrm{CE}(H)$ : enhancement effect in the bilateral cerebral hemisphere.

\section{5）血腫量と造影剤増強効果の関係（Fig． 3)}

造影剂増強効果の認められなかった症例は 10 万至 80 $\mathrm{cm}^{3}$, 平均 $38 \pm 22 \mathrm{~cm}^{3}$ であり, 患側大脳皮質にのみ認め られた症例 $(\mathrm{CE}(+))$ は 30 乃至 $80 \mathrm{~cm}^{3}$, 平均 $50 \pm 12 \mathrm{~cm}^{3}$ であった。一方両側大脳皮質に造影剂増強効果の認め られた症例 $(\mathrm{CE}(+))$ は90万至 $150 \mathrm{~cm}^{3}$, 平均 $114 \pm 27$ $\mathrm{cm}^{3}$ であり, 前 2 群との間に推計学的に有意の差が認 められた。

\section{IV. 考 察}

高血圧性脳内血腫の CT scan像に関しては, contrast enhancementにより血腫吸収過程で血腫周囲に 出現する ring enhancement が知られており ${ }^{3)}$, この出 現機序として, 血腫周囲の損傷された脳組織の修復機 転に基く, 血管新生 ${ }^{9)}$ や造影剂の血管外漏出が116) 考吕 られている。
一方, 今回我々が呈示した造影剤増強効果は, 発症 早期に出現し, 血腫内に斑状に認められるもの, ある いは血腫側のシルビウス裂, 大脳縦裂を中心とした広 範囲の大脳皮質に瀰漫性に出現しているものであり， 従来報告されてきた慢性期の造影剂増強効果とは異な るものである.

この様な造影剂増強効果が, 症状が重篤となる例に 認められたことから ${ }^{5}$, 今回, 入院時意識レベル, 発症 から CT scan 施行までの時間, 血腫型, 血腫量に関し て検討を試みた。

入院時意識レベルでは, 造影剂増強効果の認められ なかったものは10例中 9 例が 1 〜 のレベルであり， 患側大脳皮質にのみ造影剂増強効果を認めたものは前 者に比して意識障害は高度であったが, 全例刺激で覚 醒する 2 ケタ以内意識であった。ささに両側大脳皮 質に認められたものは 7 例中 6 例が意識レベル 100～300 と高度の意識障害を呈した. 又, 血腫量では, 両側大脳皮質に造影剂増強効果の認められたものは, 認められなかったもの, 患側のみに認められたものに 比して，有意に高值を示し，血腫型でも血腫が大きい ためか 7 例中 5 例が混合型であった。しかし発症から CT 施行丈での時間については差を認めなかった。以 上の如く, この造影剂増強効果は意識レベル及び血腫 量との間に夫々相関が認められ，この様な傾向は造影 剂増強効果が両側大脳皮質にすたがるような症例に顕 著であった。

この発症早期の造影剂増強効果の機序について考察 すると, 造影剂増強効果の認められた症例中, 剖検又 は手術が施行された 3 例では, いずれの例もクモ膜下 出血を認めて抢り，また 2 例に打いて血腫に接する脳 組織に限局した造影剂増強効果も認められ，脳血管撮 影に扣いて造影剂の血管外漏出を認めていることか ら, 出血の持続による造影剂の血腫腔, クモ膜下腔へ の流出がその機序の1つとしてあげられる。しかし発 症後7.5時間と比較的時間の経過した CT scan でも造 影剂増強効果を認めた症例等もあり, この出現機序と して出血の持続によるものばかりとは考えにくい.

一方，造影剂増強効果の出現は血腫量と有意に相関 し，臨床的にも意識障害が高度な例に出現しており， 剖検例に拈いては, 大脳半球の腫脹, 脳回の平坦化が 認められていることから, 造影剂増強効果の出現機序 として脳内血腫による急激な頭蓋内圧六進のため静脈 のうっ滞，怒脹による造影剤を含む血液量の増大が本 現象の出現機序の 1 つとして考兄られる. 
さて，高血圧性脳内血腫における脳循環動態の変化 に関して，血腫周囲あるいは遠隔部脳組織に局所充血 が生ずることが報告されている47). H sen ら²)はこの機序として，血腫の圧迫による局所脳 循環障害で脳組織の hypoxia, acidosis をきたし, 脳血 管運動障害を生ずるためとしており，血腫の大きさに 関係なく，発症12時間以内の急性期に認める場合もあ ると述べている.桜井ら ${ }^{10)}$ はこの様な血管運動障害を 脳血管写の capillary blush や early venous filling で とらえ, これが発症数時間の急性期に既に認められた 症例を報告している。即ち，血腫による局所脳組織圧 上昇，ひいては頭蓋内圧上昇により大脳皮質を中心に 脳血管運動障害が起こり，大脳皮質血管床が増大し， 局所脳血流量の増加とともに正常例に比べ，CT scan 上造影剂増強効果が強く現われた可能性を示唆するも のと考吕られ, 今回の造影剂増強効果の機序の 1 つと なり得るものと考える.

一方, 臨㦿的には, 造影剤増強効果の認められなかっ た症例のほとんどが軽症例であったのに対し，造影剂 増強効果の認められた症例は意識障害の高度な重症例 が多く，重症例臣と，患側大脳皮質ばかりでなく対側 大脳皮質にも明瞭に造影剂増強効果が認められている ことから, 発症早期に造影剂増強効果の認められる高 血圧性脳内血腫は症状が重篤であり，また血腫内に造 影剂増強効果の認められるものは出血の持続を示して おり,こられの症例に揖いては急激な症状増悪の可能 性があり，注意を要すると考えられた。

\section{V. 結 語}

1）発症早期の高血圧性脳内血腫21例に対し, contrast enhancement CT scan を施行し，11例に患側大 脳皮質，さらには反対側大脳皮質に造影剂増強効果の 所見を得た。

2）この造影剤増強効果出現は血腫量と有意に相関 し, 血腫の大きな例に出現しており, 臨床症状も重篤 なものが多かった.

3）この出現機序は, 脳血管反応性の障害又は頭蓋内 圧六進による大脳皮質血管床の増大によるものと考元 られた。

\section{文献}

1) Gado $\mathrm{MH}$, Phelps $\mathrm{ME}$, Coleman $\mathrm{RE}: \mathrm{An}$ extravascular component of contrast enhance- ment in cranial computed tomography. Part II : Contrast enhancement an the blood-tissue barrier. Radiology 117 : 595-597, 1975

2) $\mathrm{H} \phi$ edt-Rasmussen $\mathrm{K}$, Skinhoj E, Paulson $\mathrm{OB}$, Ewald J, Bjerum JK, Fahrenkurg A, Lassen NA: Regional cerebral blood flow in acute apoplexy "The luxury perfusion syndrome" of brain tissue. Arch Neurol 17 : 271-281, 1967

3）伊藤治英, 駒井杜討夫, 藤井博之, 古林秀則, 四十 佳伸一, 池田清延, 半田裕二, 山本信二郎： Computed Tomographyによる血腫分類と予後. 高血圧性脳出血の外科. 第7回脳卒中の外科研究会 講演集，205-210，1978

4）上村和夫, 山口昂一, 沓沢尚之：脳卒中の脳循環 一局所循環の立場から-p83-92.（大根田玄寿, 龟 山正邦, 佐野圭司, 鈴木二郎, 田崎義昭：脳卒中. 第 3 巻．脳循環。にゅうろん社，東京，1976）

5）北原正和, 小川 彰, 佐藤智彦, 小松伸郎, 桜井芳 明, 鈴木二郎：超急性期に造影剂增強効果を認め た高血圧性脳内血腫. 第四回脳神経 CT 研究会発 表演題抄録集，p96，1981

6) Kramer RA, Janetos GP, Perlstein G: An approach to contrast enhancement in computed tomography of the brain. Radiology 116: 641 -647, 1975

7) Kawakami H, Kutzuzawa T, Umeura K, Sakurai Y, Nakamura T: Regional cerebral blood flow in patients wth hypertensive intracerebral hemorrhage. Stroke 5 : 207-212, 1974

8）小川 彰, 北原正和, 佐藤智彦, 小松伸郎, 桜井芳 明，鈴木二郎：急性期高血圧性脳内出血における 造影剂強効果. 第 5 回脳神経 CT 研究会発表演題 抄録集，p156，1982

9) Pressman BD, Kirkwood JR, Davis DO : Computerized transverse tomography of vascular lesions of the brain. Part 1: Arteriovenous malformations. Part 2: Aneurisms. Amer J Roentg Rad Ther Nucl Med 124: 208-219, 1975

10）桜井芳明，伊藤善太郎，松岡茂，山口昂一： Capillary blush を伴った early venous filling の 見られた高血圧性脳出血の 1 例. 脳神経 25 ： 1733-1736, 1973 


\title{
Abstract \\ Contrast enhancement effect of CT scan in an acute stage of hypertensive intracerebral hematoma
}

\author{
Masakazu Kitahara, M.D., Akira Ogawa, M.D., Shinro Komatsu, M.D., \\ Yoshiharu Sakurai, M.D. and Jiro Suzuki, M.D.* \\ Stroke Center, Sendai National Hospital \\ *Division of Neurosurgery, Institute of Brain Diseases, Tohoku University School of Medicine
}

Twenty one patients with hypertensive intracerebral hematoma admitted within 8 hours after the onset were examined by contrast enhancement $\mathrm{CT}$ scan.

In 7 cases out of 21 , diffuse contrast enhancement effect was observed in the bilateral cerebral cortex. In 4 cases contrast enhancement effect was observed in only the affected side of cerebral henisphere. In other ten cases, contrast enhancement effect was not observed.

In cases without enhancement, the consciousness disturbance was mild and the volume of hematoma was $38 \mathrm{ml}$ on average. In cases with unilateral enhancement, disturbance of consciousness was moderate and the volume of hematoma was $50 \mathrm{ml}$. In cases with bilateral enhancements, 6 cases out of 7 were in comatous state and the volume of hematoma was $114 \mathrm{ml}$ on average. Thus the appearance of this contrast enhancement effect was significantly correlated with the level of consciousness and the volume of hematoma.

The pathogenesis of this contrast enhancement effect was discussed.

(Jpn. J. Stroke 5: 180-185, 1983) 